\title{
PERTUMBUHAN DAN HASIL KEDELAI SEBAGAI TANAMAN SELA DIANTARA TANAMAN KELAPA SAWIT DI KABUPATEN ACEH BARAT DAYA
}

\author{
Idawanni $^{*}$., Fenty Ferayanti ${ }^{1}$ \\ Balai Pengkajian Teknologi Pertanian (BPTP) Aceh \\ Jl. P. Nyak Makam No 27 Lampieneung 23125 Telp/Fax : (0651) 7551811 \\ *E-mail : Idawanniismail@yahoo.com
}

\begin{abstract}
ABSTRAK
Pengembangan kedelai sebagai tanaman sela diantara tanaman sawit belum menghasilkan umur 2 tahun untuk uji beberapa varietas kedelai merupakan salah satu alternatif untuk menambah pendapatan petani sebelum tanaman pokok menghasilkan di Kabupaten Aceh Timur. Tujuan kajian ini untuk mendapatkan varietas unggul baru kedelai yang dapat beradaptasi dan memberikan hasil tinggi pada lahan diantara tanaman kelapa sawit muda . Penelitian ini dilakukan di lahan kering pada daerah perkebunan kelapa sawit rakyat di Desa Lhok Gajah Kecamatan Kuala Bate Kabupaten Aceh Barat Daya dari bulan Maret-Juli 2019. Penelitian ini menggunakan Rancangan Acak Kelompok (RAK) dengan 4 perlakuan dan 3 ulangan, luas lahan 0,4ha. Susunan perlakuan adalah varietas Anjasmoro , Kipas Merah, Dena 1, dan Demas 1. Hasil penelitian menunjukkan bahwa varietas berpengaruh terhadap pertumbuhan dan hasil kedelai.Varietas Anjasmoro hasil tertinggi 1.90 ton ha ${ }^{1}$ diikuti varietas Dena 11.65 tonha $^{-1}$, Demas 11.50 ton $^{-1}$ dan Kipas Merah1.45 tonha ${ }^{-1}$.
\end{abstract}

Kata Kunci : Kedelai, adaptasi, varietas

\section{PENDAHULUAN}

Kedelai merupakan salah satu komoditi unggulan setelah padi dan jagung di Indonesia. Produksi kedelai nasional tahun 2017 berdasarkan Badan Pusat Statistik (BPS) sebanyak 538.728 ton biji kering kedelai. Sangat jauh sekali mengalami penurunan dari tahun sebelumnya (2016) yaitu sebanyak 859.653 ton. Besarnya permintaan kedelai belum diimbangi dengan produksi kedelai di dalam negeri. Peluang peningkatan produksi kedelai di dalam negeri masih terbuka lebar baik melalui peningkatan produktivitas maupun perluasan areal tanam.

Produksi kedelai Provinsi Aceh berdasarkan angka tetap tahun 2015 adalah sebesar 47.910 ton biji kering atau turun sebesar 15,415 ton (24,37\%) dibandingkan 2014 hal ini disebabkan akibat penurunan luas areal tanam dan panen (BPS Aceh, 2016) .Peningkatan luas areal tanam maupun panen diharapkan akan member kontribusi nyata terhadap peningkatan produksi kedelai. Salah satu upaya untuk meningkatkan areal tanam/panen adalah mengembangkan kedelai pada perkebunan kelapa sawit yang luasnya setiap tahun terus bertambah. Luas lahan perkebunan di Provinsi Aceh yang mencapai 421.820 hektaryang terdiri dari perkebunan rakyat 220.090 hektar, dan perkebunan besar 201.728 hektar (Dinas Pertanian dan Perkebunan Provinsi Aceh, 2016) merupakan suatu potensi yang sangat tinggi untuk meningkatkan produksi kedelai secara nasional.

Pengembangan kedelai sebagai tanaman sela di bawah tegakan tanaman perkebunan, hutan tanaman industri (HTI), atau tumpang sari dengan tanaman pangan semusim lain yang merupakan strategi untuk meningkatkan produksi kedelai nasional. Pemanfaatan potensi lahan di antara barisan kelapa sawit pada masa TBM dengan tanaman pangan masih terbuka, misalnya dengan tanaman padi ladang atau kedelai. Melalui pola tanam sistem tumpang sari berbasis tanaman utama, diharapkan dapat memberikan kontribusi nyata dalam mendukung ketahanan pangannasional 
(Kadekoh et al., 2007). Menanam kedelai diantara barisan juga dapat menyediakan nitrogen alami yang diikat oleh rhizobiumnya (Van Noordwijk et. al, 2004). Tambahan pula, menanam kedelai dapat meningkatkan pendapatan petani sebelum tanaman utama menghasilkan(PPKS, 2008) dan juga dapat mencegah erosi (Maryani dan Gusmawartati, 2009).

Rendahnya produksi juga dapat disebabkan antara lain masih kurangnya penggunaan benih bernutu di tingkat petani dan masih rendahnya penerapan teknologi budidaya kedelai yang spesifik lokasi.Upaya peningkatan produksi kedelai memerlukan varietas unggul berdaya hasil tinggi baik secara kuantitas maupun kualitas, serta mampu beradaptasi pada kondisi lingkungan yang kurang menguntungkan (Hutagaol, 2010). Menurut Adisarwanto (2005), untuk mencapai produktifitas maksimal dalam bertanam kedelai harus menggunakan varietas unggul yang produksinya tinggi serta tingkat adaptasi terhadap lingkungan tumbuh yang baik. Berdasarkan permasalahan diatas, maka perlu adanya pengujian beberapa varietas kedelai diantara kelapa sawit muda sebagai tanaman sela pada lahan kering dengan tujuan untuk mendapatkan varietas unggul baru kedelai yang dapat beradaptasi pada lahan diantara tanaman kelapa sawit.

\section{BAHAN DAN METODE}

Penelitian dilaksanakan di lahan kering pada daerah perkebunan kelapa sawit rakyat umur 3 tahun di Desa Lhok Gajah Kecamatan Kuala Bate Kabupaten Aceh Barat Daya, dengan ketinggian tempat 20 meter diatas permukaan laut. Penelitian ini dilaksanakan mulai dari bulan Maret - Juli 2019.

Bahan yang digunakan dalam penelitian ini benih unggul varietas Anjasmoro, Kipas merah, Dena 1 dan Demas 1 . Pupuk yang digunakan $50 \mathrm{~kg} \mathrm{ha}^{-1}$ Urea, $100 \mathrm{~kg} \mathrm{ha}^{-1} \mathrm{SP}-36,50 \mathrm{~kg} \mathrm{ha}^{-1}$ $\mathrm{KCl}$ dan dolomit $300 \mathrm{~kg} \mathrm{ha}^{-1}$. Untuk mengendalikan hama, penyakit dan gulma digunakan insektisida Demacide, Diazinon dan Herbisida Glifosat. Adapun alat-alat yang digunakan adalah gembor, cangkul, hand sprayer, meteran, timbangan Rancangan yang digunakan yaitu Rancangan Acak Kelompok (RAK) non faktorial dengan tiga ulangan. Empat varietas yang di uji yaitu varietas Anjasmoro, Dena 1, Grobogan, dan Kipas merah.Tiga varietas yang di uji berasal dari Balitkabi Malang sedangkan satu varietas Kipas Merah berasal BPTP Aceh

Penanamam dilakukan awal musim hujan pada bulan Maret, sebelum tanam lahan sudah dibuat lubang-lubang tanam dengan menggunakan tugal dengan kedalaman $3 \mathrm{~cm}$. Penanaman kedelai menggunakan jarak tanam $40 \times 15 \mathrm{~cm}$. Setelah lubang bekas tugal terbentuk kemudian 2 biji dimasukkan kedalam setiap lubang tanam dan selanjutnya ditutup kembali dengan tanah. Pemupukan dilaksanakan sesuai petunjuk budidaya, yaitu $50 \mathrm{kgha}^{-1}$ urea, $100 \mathrm{~kg} \mathrm{ha}^{-1} \mathrm{SP}-36,50 \mathrm{~kg}$ $\mathrm{ha}^{-1} \mathrm{KCl}$ dan Dolomit $300 \mathrm{~kg} \mathrm{ha}^{-1}$. Pupuk diberikan pada saat tanam dan pada umur 2 minggu setelah tanam. Pupuk diberikan dengan cara dilarik diantara barisan tanaman sekitar $10 \mathrm{~cm}$ dari lobang tanam.Untuk pengendalian hama, penyakit digunakan insektisida Demacide $1 / 2 \mathrm{sdt} / 1$ air, sedangkan pengendalian gulma dilakukan dengan menggunakan herbisida glyposhate $1,5 \mathrm{~kg} \mathrm{ha}^{-1} \mathrm{dan}$ penyiangan tangan. Penyiangan dilakukan dua kali pada umur 20 hari dan pada umur 40-45 hari

Parameter yang diamati meliputi tinggi tanaman yang di ukur mulai permukaan tanah sampai ujung daun tertinggi pada umur 30, 45 dan 60 HST, jumlah cabang dihitung pada umur 60HST, umur berbunga, jumlah polong hampa per tanaman, jumlah polong isi per tanaman, berat 100 biji, bobot biji per tanaman dan potensi hasil (ton/hektar). Komponen produksi diamati setelah panen. Data yang terkumpul dianalisis secara statistik dan untuk mengetahui pengaruh perlakuan digunakan uji lanjut Duncan pada taraf $5 \%$. 


\section{HASIL DAN PEMBAHASAN}

\section{Tinggi Tanaman}

Tabel 1 menunjukkan bahwa pada umur 30HST tinggi tanaman berbeda nyata antar varietas hal ini disebabkan tinggi tanaman sangat ditentukan oleh varietas yang di adaptasikan. Sedangkan pada umur 45HST tinggi tanaman varietas Anjasmoro memberikan hasil tertinggi yang berbeda sangat nyata dengan varietas Demas 1dan berbeda nyata dengan varietas lainnya. Umur 60 HST pertumbuhan tinggi tanaman berbeda nyata antar varietas dimana varietas Kipas Merahmemberikan hasil tertinggi yang diikuti varietas Anjasmoro.

Tabel 1. Tinggi tanaman beberapa varietas kedelai pada umur 30, 45, dan 60 hari setelah tanam

\begin{tabular}{ccccc}
\hline \multicolumn{5}{c}{ Tinggi Tanaman $(\mathrm{cm})$} \\
\hline No. & Varietas & 30 HST & 45 HST & 60 HST \\
\hline 1. & Anjasmoro & $33.45^{\mathrm{c}}$ & $46.32^{\mathrm{c}}$ & $66.40^{\mathrm{c}}$ \\
2. & Kipas Merah & $29.93^{\mathrm{a}}$ & $42.15^{\mathrm{b}}$ & $68.05^{\mathrm{d}}$ \\
3. & Dena 1 & $31.30^{\mathrm{b}}$ & $43.50^{\mathrm{b}}$ & $60.10^{\mathrm{b}}$ \\
4. & Demas 1 & $28.60^{\mathrm{a}}$ & $34.20^{\mathrm{a}}$ & $57.25^{\mathrm{a}}$ \\
\hline
\end{tabular}

Keterangan:Angka-angka yang diikuti oleh huruf yang sama menunjukkan tidak berbeda nyata (uji Duncan $0,05)$.

Pertumbuhan tinggi tanaman bervariasi dari setiap varietas akibat dari faktor genetik dari masing-masing varietas yang berbeda, sehingga pertumbuhan dilapangan juga memberikan penampilan yang berbeda, terutama dalam hal pertumbuhan tinggi tanaman. Seperti yang dikemukakan Sujitno et al. (2011) bahwa tinggi tanaman dipengaruhi oleh sifat genetik dan kondisi lingkungan tumbuh tanaman. Perbedaan pertumbuhan antara varietas tersebut dikarenakan oleh interaksi faktor lingkungan tumbuh dengan faktor genetik yang berbeda pula. Gardner, et al. (1991) menyatakan bahwa walau faktor internal perangsang pertumbuhan tanaman terdapat dalam kendali genetik, namun faktor lingkungan seperti kondisi unsur hara, iklim, dan tanah juga mempengaruhi pertumbuhan dan hasil tanaman. Wibawa (1998) menjelaskan bahwa pertumbuhan tanaman yang optimal dapat tercapai apabila unsur hara yang dibutuhkan untuk pertumbuhan dan perkembangan berada dalam bentuk tersedia, seimbang, dan dalam jumlah yang optimum.

\section{Jumlah Cabang dan Umur Berbunga}

Berdasarkan hasil sidik ragam terlihat bahwa varietas berpengaruh terhadap jumlahcabang pada umur 60 HST. Tabel 2 menunjukkan bahwa jumlah cabang pada umur 60 HST, tertinggi dijumpai pada varietas Kipas Merah yangberbeda nyata dengan varietas lainnya. Hal ini karena ada perbedaan yang mencolok antara varietas Kipas Merah dengan ketiga varietas lainnya adalah bentuk percabangan yang menyerupai kipas sedangkan pada varietas lainnya memiliki cabang yang tidak teratur.

Selanjutnya, berdasarkan hasil sidik ragam terlihat bahwa varietas berpengaruh terhadap umur berbunga. Tabel 2 menunjukkan bahwa umur berbunga dari 4 varietas yang dicobakan masih berada dalam kisaran deskripsi akan tetapiyang paling awal berbunga di jumpai pada varietas Dena 1 sedangkan umur berbunga yang yang paling telat dijumpai pada varietas Kipas Merah. Hal ini juga disebabkan sifat genetis tanaman kedelai lebih besar peranannya dalam menentukan umur berbunga. 
Semakin cepat memasuki fase pembungaan tentu akan menambah peluang suatu varietas untuk dapat membentuk polong lebih banyak (Hasnah, 2003).

Tabel 2. Jumlah cabang per tanaman dan umur berbunga beberapa varietas kedelai

\begin{tabular}{cccc}
\hline No & Varietas & $\begin{array}{c}\text { Jumlah Cabang } \\
\text { Umur 60 HST }\end{array}$ & $\begin{array}{c}\text { Umur Berbunga } \\
\text { (hari) }\end{array}$ \\
\hline 1. & Anjasmoro & $4.10^{\mathrm{a}}$ & $35,49^{\mathrm{b}}$ \\
2. & Kipas Merah & $6.00^{\mathrm{b}}$ & $41,82^{\mathrm{c}}$ \\
3. & Dena 1 & $3.00^{\mathrm{a}}$ & $28,50^{\mathrm{a}}$ \\
4. & Demas 1 & $3.20^{\mathrm{a}}$ & $34,50^{\mathrm{b}}$ \\
\hline
\end{tabular}

Keterangan:Angka-angka yang diikuti oleh huruf yang sama menunjukkan tidak berbeda nyata( uji Duncan $0,05)$.

\section{Jumlah Polong Hampa dan Jumlah Polong Isi per Tanaman}

Berdasarkan hasil sidik ragam terlihat bahwa varietas berpengaruh terhadap jumlahpolong hampa per tanaman. Tabel 3 menunjukkan bahwa jumlah polong hampa per tanaman tertinggi dijumpai pada varietas Demas 1yang berbedanyata dengan varietas lainnya.

Nilahayati dan Putri (2015) menyatakan bahwa selain faktor genetis, proses pengisian biji yang dapat mempengaruhi ukuran biji juga ditentukan oleh faktor pembungaan dan lingkungan yang mendukung. Hal ini juga dinyatakan oleh Lakitan (1994), salah satu faktor pendukung proses fotosintesis adalah ketersediaan cahaya yang cukup, dimana hasil fotosintesis adalah ketersediaan cahaya yang cukup, dimana hasil fotosintesis selanjutnya akan ditrasnlokasikan ke organ penampung (sink) yaitu bunga, buah dan biji.

Tabel 3. Jumlah polong hampa per tanaman dan jumlahpolong isi per tanamanbeberapa varietas

\begin{tabular}{llcc}
\multicolumn{3}{c}{ kedelai } & \\
\hline No & \multicolumn{1}{c}{ Varietas } & Jumlah & Jumlah Polong Isi/ Tanaman \\
& & Polong Hampa/ Tanaman & $101,2^{\mathrm{d}}$ \\
\hline 1. & Anjasmoro & $8,10^{\mathrm{b}}$ & $77,52^{\mathrm{a}}$ \\
2. & Kipas Merah & $11.40^{\mathrm{c}}$ & $84,30^{\mathrm{b}}$ \\
3. & Dena 1 & $7,60^{\mathrm{a}}$ & $95,20^{\mathrm{c}}$ \\
4. & Demas 1 & $12,20^{\mathrm{d}}$ &
\end{tabular}

Keterangan:Angka-angka yang diikuti oleh huruf yang sama menunjukkan tidak berbeda nyata( uji Duncan $0,05)$.

Berdasarkan hasil sidik ragam terlihat bahwa varietas berpengaruh terhadap polong isi pertanaman. Tabel 3.menunjukkan bahwa jumlah polong isi per tanaman tertinggi di jumpai pada varietas Anjasmoroyang berbeda dengan varietas lainnya. Perbedaan dari jumlah polong isi per tanaman diduga disebabkan oleh pengaruh genetik dari masing-masing kultivar yang berbeda (Guswara, 2007). Namun selain dari pengaruh genetik, faktor lingkunganpun mempengaruhi jumlah polong isi per tanaman dari masing-masing varietas dalam pembentukan bunga pada setiapcabang. Hal ini sesuai dengan pernyataan Taufik et al. (2010) bahwa dengan meningkatnya serapan hara, maka kebutuhan hara lebih terpenuhi dan metabolisme berjalan secara optimal sehingga pembentukan protein, karbohidrat, dan pati tidak terhambat, akibatnya akumulasi bahan 
metabolisme pada pembentukan biji akan meningkat sehingga biji yang terbentuk mempunyai ukuran dan bobot yang lebih besar.

\section{Bobot 100 Biji dan Bobot Biji per Tanaman dan Potensi Hasil/ha}

Berdasarkan hasil sidik ragam terlihat bahwa varietas berpengaruh terhadap bobot 100 biji. Tabel 4.menunjukkan bahwa bobot 100 biji tertinggi diperoleh pada varietas Anjasmoro yang berbeda nyata dengan varietas lainnya.Perbedaan bobot 100 biji yang dihasilkan erat kaitannya dengan kemampuan masing-masing varietas menyerap hara yang tersedia, terutama P. Hal ini sesuai dengan pendapat Warisno (1998) bahwa penyerapan P yang berbeda akan menyebabkan fotosintat yang dihasilkan oleh tanaman kedelai berbeda sehingga hasil fotosintesis yang ditraslokasikan untuk kebutuhan pengisian biji menjadi berbeda.

Berdasarkan hasil sidik ragam menunjukkan bahwa varietas berpengaruh terhadap bobot biji per tanaman.Tabel 3menunjukkan bahwa varietas Anjasmoro memiliki rata-rata bobot biji per tanaman tertinggi yang berbeda nyata dengan varietas lainnya. Sedangkan varietas Demas 1, dan Kipas merah, bobot biji per tanaman tidak berbeda nyata.

Tabel 4. Berat 100 biji dan potensi hasil per hektar beberapa varietas kedelai di Desa Lhok Gajah Kabupaten Aceh Barat Daya

\begin{tabular}{lcccc}
\hline No & Varietas & Bobot 100 Biji (g) & $\begin{array}{c}\text { Bobot Biji per } \\
\text { Tanaman }(\mathrm{g})\end{array}$ & $\begin{array}{c}\text { Potensi Hasil } \\
\text { (ton/hektar) }\end{array}$ \\
\hline 1. & Anjasmoro & $15,20^{\mathrm{b}}$ & $123,00^{\mathrm{c}}$ & $1.90^{\mathrm{b}}$ \\
2. & Kipas Merah & $11,70^{\mathrm{a}}$ & $90,10^{\mathrm{a}}$ & $1,45^{\mathrm{a}}$ \\
3. & Dena 1 & $13,00^{\mathrm{a}}$ & $98,80^{\mathrm{b}}$ & $1,65^{\mathrm{a}}$ \\
4. & Demas 1 & $12,20^{\mathrm{a}}$ & $92,00^{\mathrm{a}}$ & $1,50^{\mathrm{a}}$
\end{tabular}

Keterangan:Angka-angka yang diikuti oleh huruf yang sama menunjukkan tidak berbeda nyata ( uji Duncan $0,05)$.

Pengisian biji didasarkan pada jumlah pati (asimilat) yang terakumulasi dalam spikelet, yang sangat ditentukan selama fase pengisian biji. Ada 3 faktor penting selama proses pengisian biji, yaitu : 1. produksi fotosintat yang dihasilkan oleh organ tanaman yang berperan sebagai source, 2. sistem translokasi dari sumber ke limbung, dan 3. akumulasi fotosintat pada sink. Hasil dari proses pengisian biji adalah keseimbangan dari ketiganya (Khush,1996). Bobot 100 biji juga diduga lebih banyak ditentukan oleh kemampuan pengisian biji yang bervariasi antar varietas. Sesuai pendapat Lautt et al. (2000) proses ini berkaitan dengan distribusi karbon ke biji yang dipengaruhi oleh perimbangan pati-sukrosa dan melibatkan aktivitas enzim sukrosa fosfat sintase (SPS).

Berdasarkan hasil sidik ragam menunjukkan bahwa varietas berpengaruh terhadap potensi hasil per hektar, Tabel 4menunjukkan bahwa varietas Anjasmoro memiliki rata-rata potensi hasil per hektar tertinggi yang berbeda nyata dengan varietas lainnya. Hal ini diduga karena perbedaan faktor genetik dari masing-masing varietas yang juga menjadi penyebab perbedaan hasil atau produksi. Hal ini sesuai dengan pernyataan Kamal (2001), perbedaan hasil total disebabkan oleh perbedaan komposisi genetik dari masing-masing kultivar Kedelai, sehingga responnya terhadap lingkungan juga berbeda. Tidak hanya genetik, faktor lingkungan juga berpengaruh pada produksi tanaman, lingkungan yang berpengaruh tersebut berupa cahaya matahari, curah hujan dan unsur hara dalam tanah. 
Hal ini sesuai dengan pendapat Satoto dan Suprihatno (1998) bahwa karakter hasil merupakan karakter yang kompleks yang dikendalikan oleh sejumlah besar gen-gen kumulatif, duplikat, dan dominan yang sangat dipengaruhi oleh lingkungan. Selain itu hasil penelitian Marzuki et al. (1997) juga menunjukkan bahwa faktor lokasi, musim, varietas unggul berpengaruh terhadap hasil. Sesuai pendapat Soewitoet al.(1995)varietas unggul merupakan salah satukomponen teknologi yang memiliki peran nyata dalam meningkatkan produksi dan kualitas hasil komoditas pertanian.

\section{KESIMPULAN}

Hasil penelitian menunjukkan bahwa varietas Anjasmoro berpengaruh terhadap pertumbuhan dan hasil Kedelai sebagai tanaman sela diantara tanaman kelapa sawit muda. Varietas yang terbaik di jumpai pada varietas Anjasmoro terhadap, jumlah polong isi per tanaman $(101,2)$, bobot 100 biji $(15,20)$, Bobot biji per tanaman $(123,00)$ dan potensi hasil $\left(1,90\right.$ ton $^{-1)}$ dan diikuti varietas Dena $1\left(1,65\right.$ ton $\left.^{-1}\right)$, varietas Demas $1\left(1,50\right.$ ton $\left.^{-1}\right)$ dan varietas Kipas Merah $\left(1,45\right.$ ton $\left.^{-1}\right)$.

\section{DAFTAR PUSTAKA}

Adisarwanto, T; 2005. Kedelai. Penebar Swadaya, Jakarta.

Biro Pusat Statistik. 2017. Statistik Pertanian di Indonesia. Badan Pusat Statistik. Jakarta.

Biro Pusat Statistik, 2016. Aceh Dalam Angka Tahun 2015. Biro Pusat Statistik Aceh, Banda Aceh.

Dinas Pertanian dan Perkebunan Provinsi Aceh, 2016. Statistik Perkebunan Indonesia 2014-2016.

Komodias Kelapa Sawit. Banda Aceh

Gardner, F. P. R. B. Pearce dan R. L Mitchell. 1991. Fisiologi Tanaman Budidaya (terjemahan Herawati Susilo). Universitas Indonesia. Jakarta.

Guswara, A. 2007. Peningkatan Hasil Tanaman Padi Melalui Pengembangan Padi Hibrida : Dalam Kumpulan RDTP/ROPP. Balai Besar Penelitian Tanaman Padi. Sukamandi. Subang.

Hasnah. 2003. Pengaruh naungan terhadap pertumbuhan kedelai dan kacang tanah. Jurnal Agromet $8(1): 21-40$.

Hutagaol, R. L. 2010. Uji Keragaman karakter Vegetatif dan Generatif Beberapa Varietas Kedelai (Glycine max L.) dengan Sistem Baris. Skripsi. Departemen Budidaya Pertanian, Fakultas Pertanian, Universitas Sumatera Utara. Medan.

Kadekoh,A. 2007. Optimalisasi Pemanfaatan Lahan Kering Berkelanjutan dengan Sistim Polikultur. hal : 27-33. Prosiding seminar Nasional Pengembangan Inovasi Lahan Marginal.

Kamal, F. 2001. Parameter genetik Beberapa Galur Introduksi Padi Sawah (Oryza sativa L). Skipsi. Program Studi Agronomi, Fakultas Pertanian, Universitas Andalas. Padang.

Kush. G. S. and R. C. Aquino. 1996. Breeding For High Yield Potential In Rice. The International Rice Research Conference. 27 - 31 Augustus. Seoul, Korea.

Lakitan, B. 1994. Dasar-dasar Fisiologi Tumbuhan. Jakarta: RajaGrafindo Persada.

Lautt, B.S., M.A. Chozin, D. Sopandie, L.K. Darusman. 2000. Perimbangan pati-sukrosa dan aktivitas enzim sukrosa fosfat sintase pada padi gogo yang toleran dan peka terhadap naungan. Hayati 7(2): 31-34.

Marzuki, A.R., A. Kartohardjono, dan H. Siregar. 1997. Potensi hasil beberapa galur padi resisten wereng batang coklat. Hal 118-124 Prosiding Simposium Nasional dan Konggres III PERIPI, Bandung 24-25 September 1997. 
Maryani dan Gusmawartati, 2009. Uji Beberapa Dosis N,P, K dan Jarak Tanam terhadap Produksi Kedelai (Glycine max (L) Merril) yang Ditanam di antara Kelapa Sawit, Laporan Hasil Penelitian. LPPM Universitas Jambi. Jambi

Nilahayati dan L.A.P. Putri. 2015. Evaluasi keragaman karakter fenotip beberapa varietas Kedelai (Glycine max L.) di Daerah Aceh Utara. Jurnal Floratek 10: 36 - 45

PPKS (Pusat Penelitian Kelapa Sawit) Marihat Indonesia. 2008. Tanaman Pangan Sebagai Cover Crop pada Pertanaman Kelapa Sawit Belum Menghasilkan (TBM). Medan.

Soewito, T; S. Harahap dan Suwarno. 1995. Perbaikan varietas Padi Sawah Mendukung Pelestarian Swasembada Beras. dalam Prosiding Simposium Penelitian Tanaman Pangan III, Jakarta. 23-25 Agustus 1995.

Sujitno, E.,T. Fahmi dan S. Teddy., 2011. Kajian adaptasi beberapa varietas unggul padi gogo pada lahan kering dataran rendah di Kabupaten Garut. Jurnal Pengkajian dan Pengembangan Teknologi Pertanian 14(1): 62-69

Taufik, S., Baharom, S., Xiao, R.Y., 2011. Predicted Bahaviour of Partially Restrained Conection With Cold Formed High Srenght Steed by 3D Finite Element Modelling, International Journal of advanced Materials Research, 250-253 pp

Warisno. 1998. Jagung Hibrida. Kanisius. Yogyakarta.

Wibawa, A. 1998. Intensitas Pertanaman Kopi dan Kakao Melalui Pemupukan. Warta Pusat Penelitian Kopi dan Kakao. 14 (3) : 245-262.

Van Noordwijk, M.,G.Cadist and G.K.Ong. 2004. Below ground interactions in Tropical Agrosystem. Concepts and models with Mutiple Plant Components. CABI Publishing. 439p. ISBN 0- 85199-673-6 